\title{
The study of relationship between social identity dimensions and the individual differentiation
}

\author{
Mohammad Solgi ${ }^{1}$ \\ 1-Assistant Professor, Department of Psychology, Jahad Daneshgahi - Academic Center for Education, Culture \& \\ Research (ACECR), Tehran, Iran (Corresponding Author). \\ E-mail: solgy204@yahoo.com \\ Received: 29/03/2020 \\ Accepted: 08/06/2020
}

\begin{abstract}
Introduction: Personal identity is among the topics that concerns not just psychology but other sciences as well; different definitions and descriptions have been offered; the effective and affected factors have been analyzed too. Personal identity is one's definition of one's self with the main emphasis being on one's contradistinction from the other

Aim: The aim of this study was to investigate the relationship between social identity dimensions and the individual differentiation.

Method: The present study was a descriptive-correlational study; the study population consisted of all citizens ranging from 15 to 65 years old in 2016. Based on multistage cluster random sampling 1300 samples were chosen from seven different county seats in Iran (cities being: Tehran, Mashhad, Shiraz, Rasht, Tabriz, Sanandaj and Ahwaz.) Measuring tools were researcher-made questionnaires and Data were analyzed using statistical method of correlation coefficient

Results: According to the findings of this study, there exists a meaningful and positive correlation between the ethical aspect of identity and individual differentiation $(t=0.822$ and $\mathrm{Sig}=0.532$ ) There exists a meaningful and positive correlation between the religious aspect of identity and individual differentiation $(\mathrm{t}=3.274$ and $\mathrm{Sig}=0.001)$. Also, between traditionalism and the individual differentiation there exists a meaningful and negative correlation $(\mathrm{t}=-0.544$ and Sig=0.587).

Conclusion: Findings showed that the dimensions of social identity consisting of religious, and ethical aspects of identity have an important role in predicting the individual differentiation in the Iranian sample.
\end{abstract}

Keywords: Individual differentiation, Religious identity, Ethical identity, Social identity, Traditionalism

\footnotetext{
How to cite this article : Solgi M. The study of relationship between social identity dimensions and the individual differentiation. Shenakht Journal of Psychology and Psychiatry. 2020; 7 (3): 101-111 .URL: http://shenakht.muk.ac.ir/article-1-997-en.pdf

Copyright $\odot 2018$ the Author (s). Published by Kurdistan University of Medical Sciences. This is an open access article distributed under the terms of the Creative Commons Attribution-Non Commercial License 4.0 (CCBY-NC), where it is permissible to download, share, remix, transform, and buildup the work provided it is properly cited. The work cannot be used commercially without permission from the journal.
} 


\section{مطالعهى رابطه بين ابعاد هويت اجتماعى با ميزان تمايز يافتكى فردى}

محمد سلكى'

ا.استاديار، گروه روانشناسى، جهاد دانشآهى، تهران، ايران (مولف مسئول). ايميل: yahoo.com @ solgy204

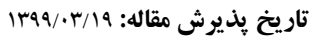

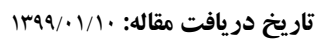

جكيده

مقدمه: هويت فردى از موضوعاتى است كه علاوه بر روانشناسى ساير علوم ديخر نيز به آن توجه كرده و تعاريف و توصيفات متفاوتى

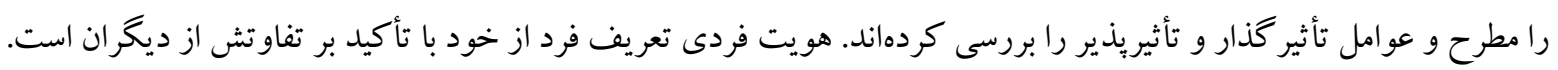
هدف: هدف يُزوهش حاضر عبارت بود از بررسى ارتباط بين ابعاد هويت اجتماعى با ميزان تمايز يافتكى فردى. روش: روش تحقيق اين مطالعه از نوع مطالعات توصيفى و همبستخى است و جامعه آمارى اين طرح شامل كليه شهروندان در رده سنى

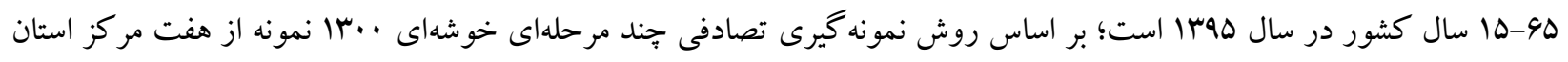

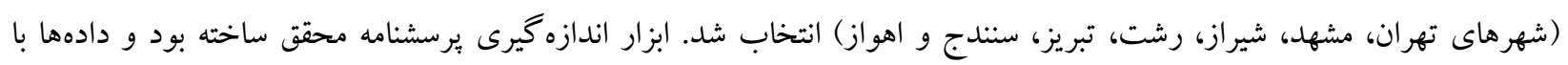

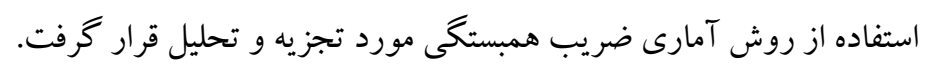

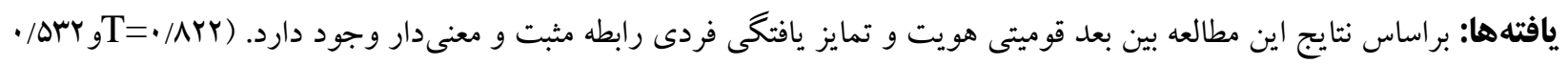

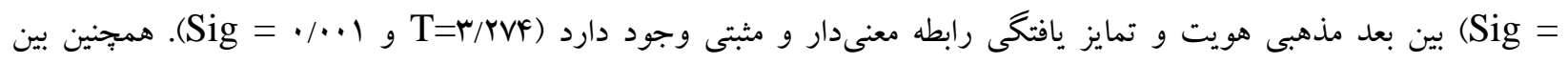

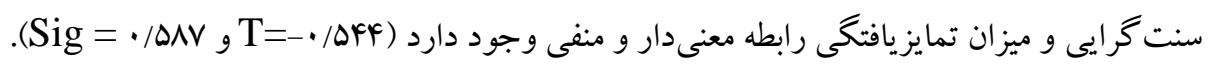
نتيجه كيرى: يافتها نشان داد كه ابعاد هويت اجتماعى متشكل از متغيرهاى بعد مذهبى هويت و همجنين بعد قومى نقش مهمى در بيش بينى تمايز يافتكى هويت فردى در نمونه ايرانى دارد. كليدوازهها: تمايز يافتكى فردى، هويت مذهبى، هويت قومى، هويت اجتماعى، سنت گرايى 
شناخت خود و شناساندن خود به ديخران؛ اين دو عمل

مقدمه

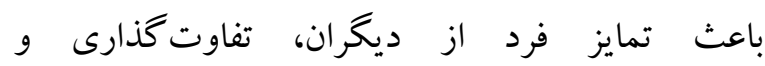
دكر گونهسازى مىشود. فر آيندى كه تحت عنوان تمايز

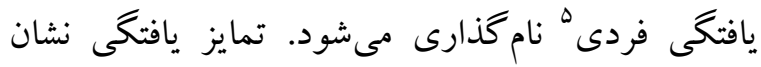
دهنده گذراندن موفق دوران زندگى فرد است و فرآيند هويتيابى است و نقشى مهم و اساسى در برخوردارى از

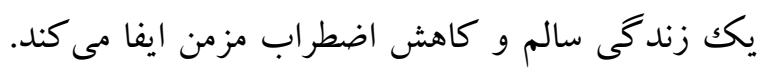
هويت هر شخص را نبايد در رفتار او و در واكنشهاى

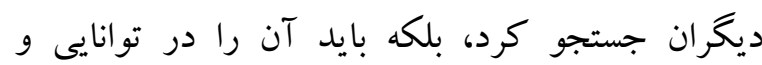
ظرفيت وى براى حفظ و ادامه روايت مشخصى از زند گينامهاش يافت؛ زندگى نامه شخصى كه به حفظ روابط متقابل و منظم با ديخران علاقهمند است، خيالى و ياهي

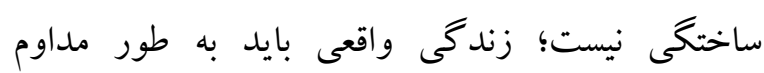
رويدادهاى دنياى خارج را در خود ادغام كند و آنها را با تاريخجه جارى (اخود) شخص ساز كار سازد (نونان،

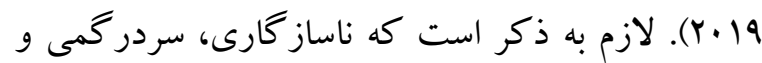

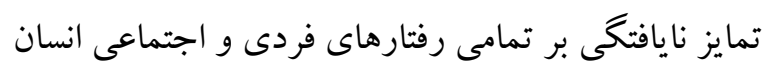
اثر مى گذرد. ناتوانى در ايجاد ارتباط با همسالان،

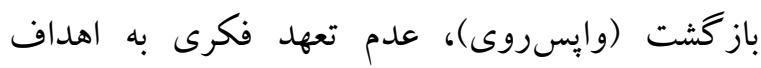
خاص، عدم تمايل به مذهب و مسلكك خاص، عدم إمار دستيابى به نظام باورها و ارزشها، فقدان استراتزى و هدف در زندگى، لاقيدى در رفتار، تأكيد بر زندگى

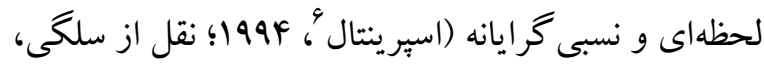
هA براى آينده، حركت در حال و اكنون به نحوى غير ارادى، روابط مختل با والدين (نصرتى و همكاران، هربا)، آسيبيذيرى اجتماعى و... بارهاى از اوصاف يك فرد سردرگم و يريشان نقش است. در برخى تقسيمبندى واعها

5- Individual differentiation

${ }^{6}$ - Sprintal

هويت' يكى از مفاهيم اساسى در روانشناسى است كه مورد علاقه بسيارى از متخصصان علوم انسانى است.

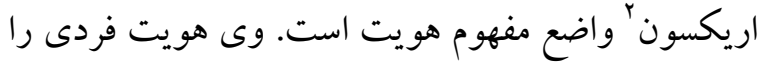
به صورت يك احساس نسبتاً بايدار از يكانكى خود

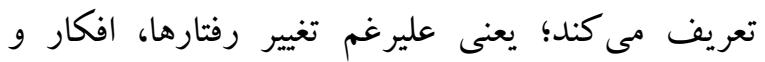
احساسات، برداشت يكك فرد از خود همواره مشابه است. محققان مقوله هويت را فرايند دستيابى به احساس بايدار از كيستى (كه هستم؟) و اينكه إكه بايد باشم) مىداند

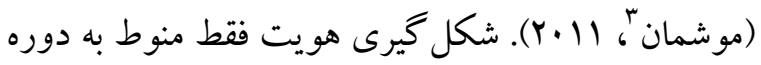
نوجوانى نيست؛ بلكه مربوط به سراسر عمر انسان است كه

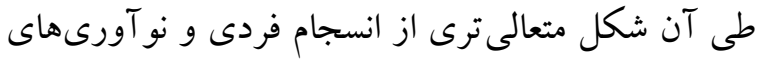

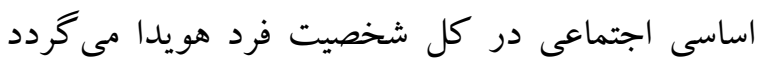

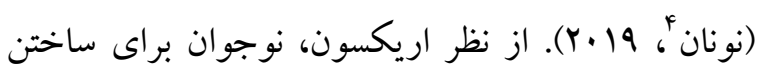

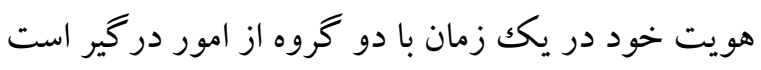
از سويى بايد با تغييرات فيزيولوزيكى و شناختى خود برد

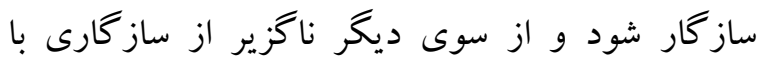
نظامهاى بيرونى است. نوجوان بايد با تمام اين مسائل

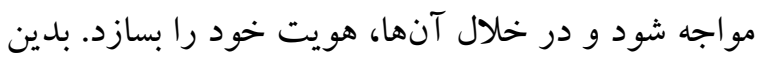
ترتيب ساختن يكك هويت منسجم و سالم نمى تواند آسان و بدون مشكل باشد (نونان، 19 ـr). بر اساس مبانى نظرى

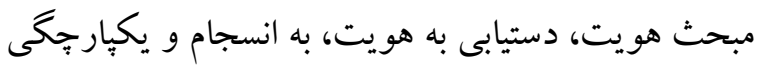
(من) مى انجامد و در سوى مقابل، عدم دستيابى به هويت،

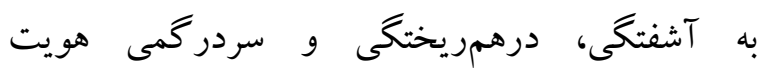
مى مانجامد. در فرايند شكل گيرى هويت فردى دو عمل

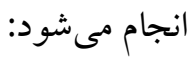


اجتماعى در سازههايى جون: نسل، طبقه، ملت، قوميت و

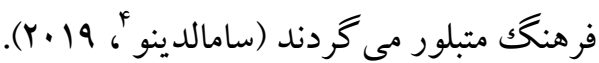
در بررسى بيوند بين شكل گيرى هويت فردى (تمايزيافتكى هويت فردى) و همجِنين لايههاى هويت اجتماعى جند ضرورت وجود دارد از جمله اينكه معمولاً روانشناسان به بررسى ابعاد، مؤلفها، منابع، هميجنين بحرانها و آسيبهاى هويت فردى عنايت دارند. جامعهشناسان نيز موضوع هويت را در سطح جمع و كروههاى اجتماعى بررسى مى كنند و به ابعاد و سطوح متكثر آن همجيون دينى، قومى (محلى) و جهانى (متجدد) توجه دارند (سلكى، 9مبا). در اين ميان خلأهايى ديده مىشود كه از سو گيرى هر يكك از اين دو حوزه علمى [معطوف به فرد و جمع] نشات گرفته است. از جمله كاستىها در اين حوزه، شمار اندكك بزوهشهايى است كه به بررسى تعامل دو سطح هويت (فردى - اجتماعى) يرداختهاند. از آنجا كه هر نوع تزلزل، گسست، تأخير و كمرنكى در هويت فردى و تمايز يافتكى، انسجام شخصيت را به مخاطره مى اندازد و در سطح اجتماعى نيز يايههاى نظم و انسجام اجتماعى را سست مى سازد. لذا از منظر بهداشت روانى انسجام هويت جه در سطح فرد و جه در سطح جمعى يكك ضرورت تلقى مى گردد. اين رويكرد به انجام ئزوهشهاى ميانرشتهاى نيازمند است كه از جمله نيازهاى جامعه ما محسوب مى مى خردد؛ بنابراين شناسايى عوامل مرتبط با هويت فردى و شناخت رابطه بين هويت اجتماعى و ميزان تمايز يافتكى هويت فردى در افراد فعال جامعه (گروه سنى ها تا لهال سال) نسبت به ترسيم نيمرخ هويت فردى آنان از اهميت بالايى دارد. بر اساس جنين ديدگاهى در تحقيق حاضر هويت

4- Smaldino
هويت را به ب وجه فردى، اجتماعى و ملى تقسيم مى كنند

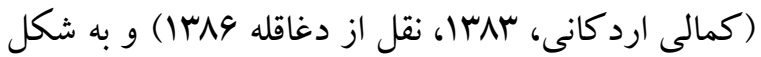
كلى مى توان كفت كه هويت فردى بر تفاوتها تأكيد دارد در حالى كه تأكيد اصلى هويت جمعى بر شباهتهاست و اين ابعاد باهم ارتباط و تعامل يويايى

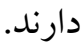
تحقيقات حاكى از آن است كه لايههاى ديخر هويت (از جمله اجتماعى و ملى) و تغييرات ساختارى اجتماعى نيز ممكن است فرآيند هويت يابى و تمايز يافتكى هويت فردى را نيز تحت تأثير قرار دهند به عنوان مثال مارسيا (1919) نشان داد كه تغييرات تاريخى، اقتصادى و سياسى بر عادات و سنتها اثر كذاشته و باعث افزايش هويت

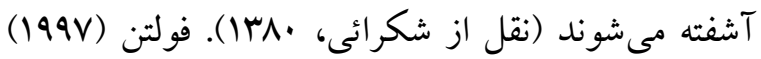
نيز رابطه مثبت بين هويت دينى و هويت موفق، همجنين رابطه منفى هويت دينى با هويت آشفته و معلق را نشان داد. اين يافته ها حاكى از آن است كه هويت مى تواند

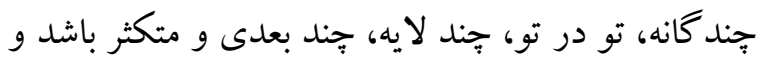
اصولاً هويت شامل مجموعههاى محققى است كه طى لى نـ مراحل زندگى در خود انباشت مى كنيم و الزاماً اين

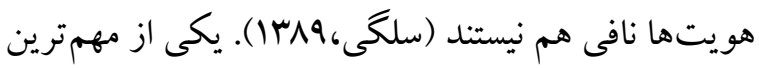

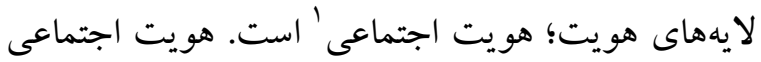
از بايگاهى نشئت مى گيرد كه فرد در جامعه در آن قرار

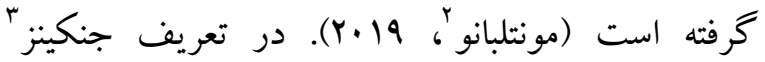

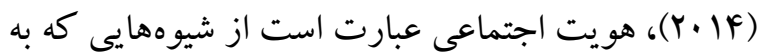
واسطه آنها فرد و جماعات از هم متمايز مىشوند و حاصل آن برقرارى روابط و بيوندهاى هويتى و متمايز

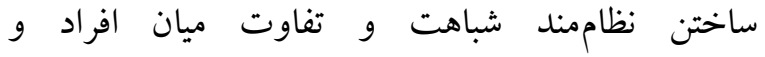

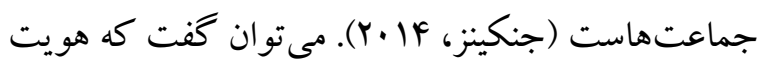

\footnotetext{
- Social Identity

2- Montalbano

3 - Jenkins
} 
شناخت اين اقدام، سياست گذارى و برنامهريزىهاى ذى بربط در حوزه مسائل انسانى را سهل و مقدور خواهد

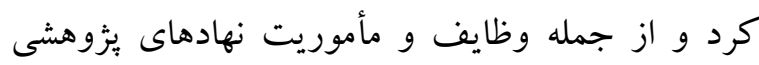

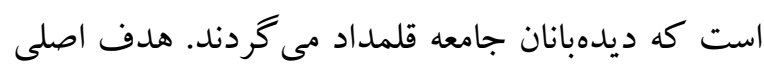
اين يزووهش بررسى ارتباط بين ابعاد هويت اجتماعى

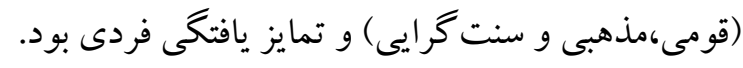

\section{روش}

يُزوهش حاضر از نوع مطالعات توصيفى و همبستخى است. جامعه آمارى اين طرح شامل كليه شهروندان در رده سنى 90-10 سال در سراسر مراكز استانهاى كشور

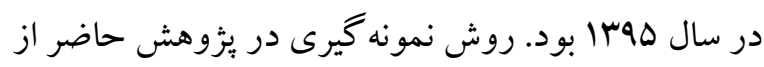

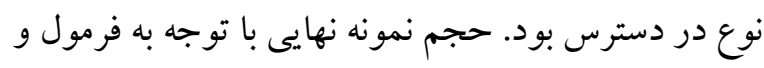
ملاحظات اجرايى IrN| است. در اين طرح به لحاظ تناسب تقسيمات ميان هفت استان موردبررسى و با توجه به موارد مطرح شده، حجم ..rا نمونه براى كل كشور در نظر كرفته شد. بر اساس حجم برآورد شدة ...

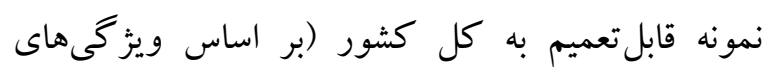

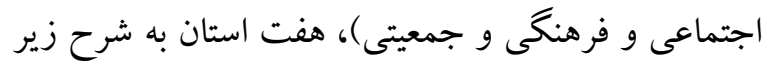
به صورت تصادفى انتخاب شدند:

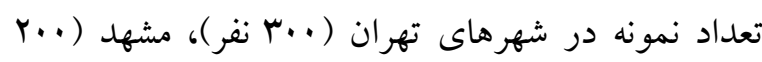

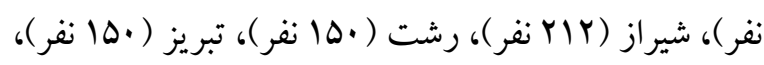

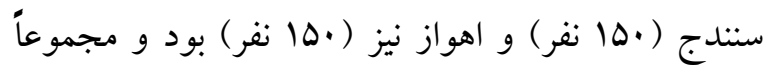

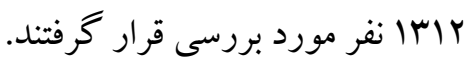

ابزار

ابزار اندازهيرى در اين بثوهش برسشنامه محقق ساخته

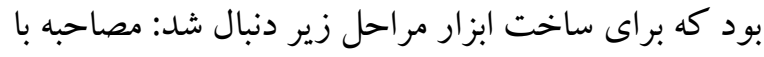
صاحبنظران و مرور نظرى نظريات حوزه هويت فردى،

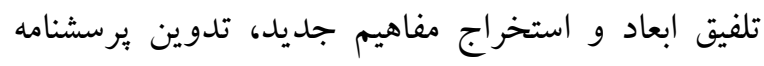

اجتماعى در سه سطح مذهبى هويت، بعد قوميت گرايى

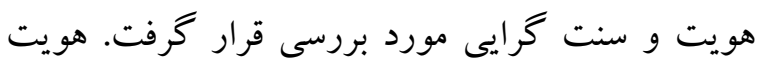
دينى و مذهبى مجموعهاى از ارزشهاى فردى است كه به صورت برداشتهاى مذهبى، علمى و اجتماعى نمايان مى شود. بسيارى از جوانان داشتن نوعى فلسفه زندگى را براى خود، ضرورى مىداند، وقتى براى اولين بار به دنياى اطراف خود مىنغرند و سعى مى كنند تا شخصيت خود را ارزيابى نمايند، احساس مى كند كه درباره جهان و معناى وجود انسان و حتى خودشان نيازمند باسخ هستند

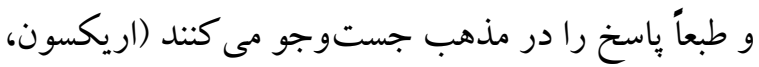

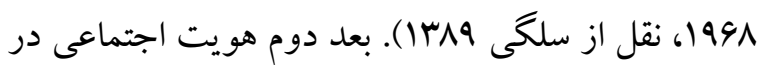
اين ئزوهش هويت قومى' است. هويت قومى به عنوان يكى از سطوح جامعهيذيرى تعريف مىشود كه فرد خود را با يك كروه بزر گك قومى متصل و مربوط مى كند و از آن طريق به صورت نمادين يا واقعى خود را عضو آن

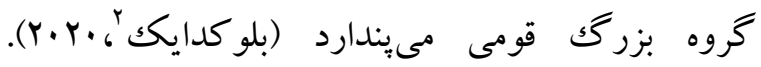
سومين مؤلفه بر اهميت هويت اجتماعى ارزشهاى سنتى است. منظور از ارزشهاى سنتى در اين نوشتار ارزشهاى

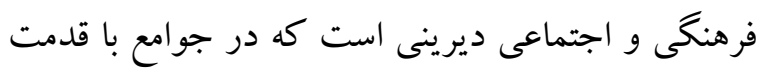

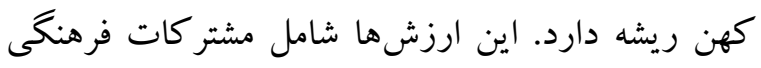
اعم از: سرزمين، زبان، نمادهاى ملى و سنتى و ادبيات

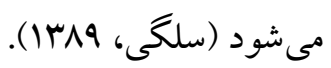

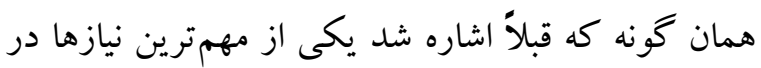

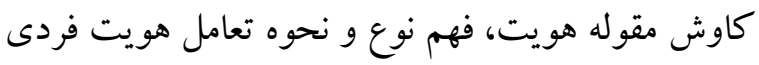

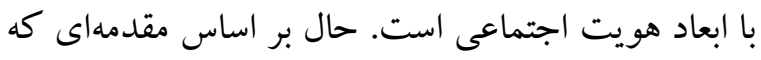
ذكر شد به نظر مىرسد در جامعه ايرانى وضعيت ارتباط بين لايههاى هويت اجتماعى با هويت فردى و ميزان تمايزيافتكى فردى حجندان مشخص نيست. از آنجا كه

\footnotetext{
1 - Ethnic identity

2- Blokdyk
} 
ابزار تحقيق از آزمون الفاى كرونباخ استفاده شده كه

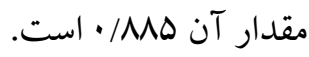

يافتهها

در خصوص ياسخگويان مىتوان كفت همان گونه كه ذكر شد تعداد كل باسخگ

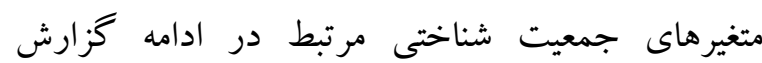

$$
\text { مى شود. }
$$

اوليه، بيش آزمون و اصلاح برسشنامه و يرسشنامه نهايى.بعد از اعمال نظرات صاحبنظران، يرسشنامه اوليه براى اجرا آماده و بين ·r نفر از جامعه آمارى توزيع و از ايشان خواسته شد تا به سؤالات باسخ دهند. بعد از تكميل برسشنامه توسط ياسخكويان، دادههاى به دست آمده مورد تحليل قرار گرفت. براى به دست آوردن يايايى

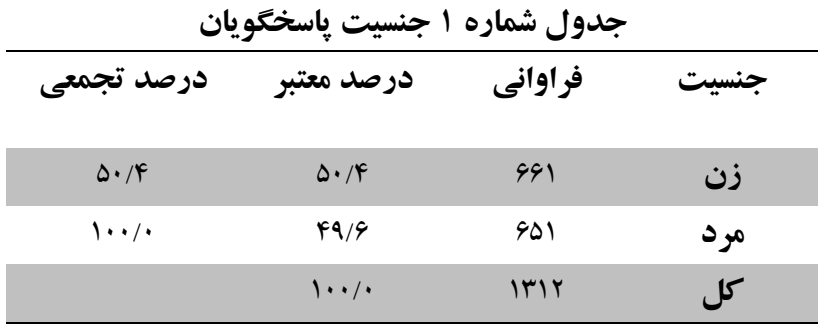

تر كيب جنسى باسخگو يان حاكى از آن است كه \&/ •ه درصد از باسخگو يان زن و \$9/9 درصد مرد است.

جدول ץ سن پاسخخَويان

\begin{tabular}{|c|c|c|c|c|c|}
\hline انحراف معيار & ميانغين & درصد تجمعى & درصد معتبر & فراوانى & \\
\hline \multirow[t]{6}{*}{$\mid f / .9$} & \multirow[t]{6}{*}{$\Gamma / / \Lambda$} & $r 9 / r$ & $r q / r$ & FVI & زير •r سال \\
\hline & & $\Delta \mathrm{V} /$. & $r \cdot / \Lambda$ & PVI & 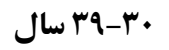 \\
\hline & & $V r / v$ & $19 / \mathrm{V}$ & riv & fq-r. \\
\hline & & $\Lambda V / \Delta$ & $1 \% / 1$ & IV9 & 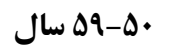 \\
\hline & & $1, \cdots /$ & $1 r / \Delta$ & 194 & بالاى •ع سال \\
\hline & & & $1 \ldots /$ & $1 r \cdot 1$ & كل \\
\hline
\end{tabular}

بالاى .9 سال هستند. سن كوجّكترين باسخگو 19 و نتايج به دست آمده از تر كيب سنى باسخگ يان در جدول بزرگكترين وِاسخگ

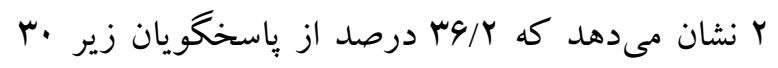

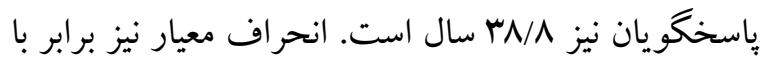

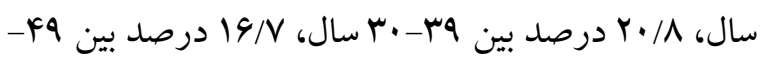
. $1 \%$ / 19

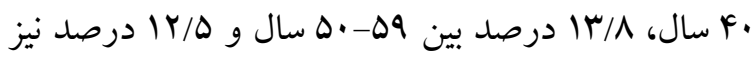

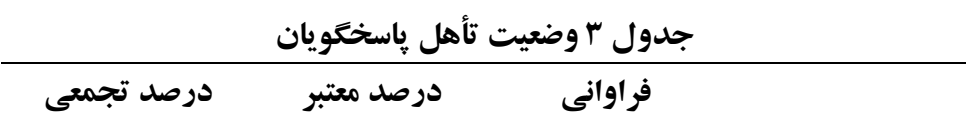




\begin{tabular}{|c|c|c|c|}
\hline$r q / r$ & $r q / r$ & rVI & مجرد \\
\hline $9 \Delta / r$ & $90 / 9$ & NGG & متأهل \\
\hline $99 / 1$ & $1 / V$ & rI & مطلقه \\
\hline $1 \cdots /$ & $r / r$ & f. & فوت همسر \\
\hline & $1 \cdots /$ & IYGA & كل \\
\hline
\end{tabular}

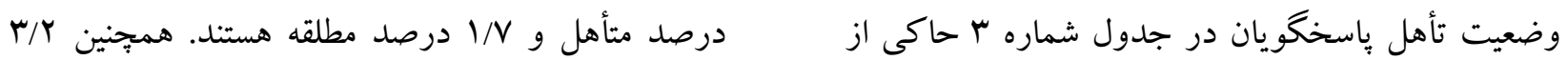

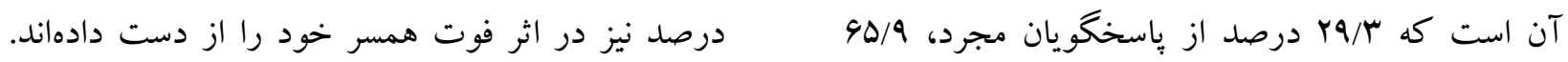

\begin{tabular}{|c|c|c|c|}
\hline \multicolumn{4}{|c|}{ جدول ب قوميت پاسختويان } \\
\hline درصد تجمعى & درصد معتبر & فراوانى & \\
\hline $\mathrm{Fq} / \mathrm{I}$ & $\mathrm{Fq} / \mathrm{I}$ & 949 & 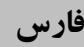 \\
\hline $9 / / \pi$ & $19 / 4$ & rFG & 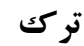 \\
\hline$\lambda \cdot / F$ & $|r /|$ & 100 & كرد \\
\hline$\Lambda \Delta / \cdot$ & F/9 & $\Delta q$ & عرب ع ع ع ع مب \\
\hline $\mathrm{NV} / 9$ & $r / 9$ & $\pi$ & ل \\
\hline $9 V / 9$ & $1 . \%$ & ira & كيلكى \\
\hline $1 . \cdots /$ & $r / F$ & ri & ساير \\
\hline & $1 \cdots /$ & $|r \Lambda|$ & كل \\
\hline
\end{tabular}

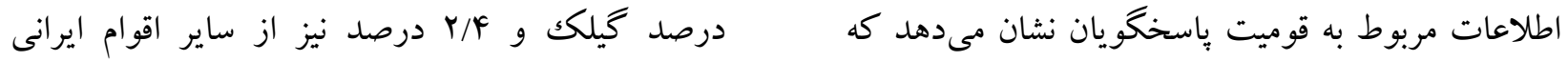

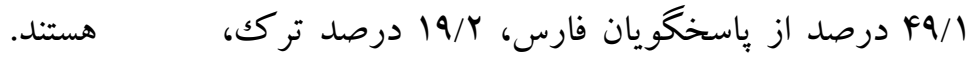

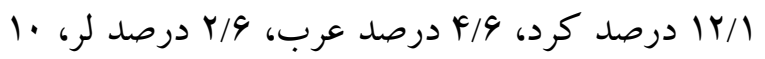

\begin{tabular}{|c|c|c|c|}
\hline \multicolumn{4}{|c|}{ جدول ه تحصيلات ياسخگَويان } \\
\hline درصد تجمعى & درصد معتبر & 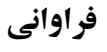 & \\
\hline$f / \Delta$ & $F / \Delta$ & $\Delta q$ & بىسواد \\
\hline $\mathrm{IV} / \cdot$ & $1 Y / \Delta$ & 194 & ابتدايى \\
\hline$r \cdot / q$ & $1 r / f$ & IVF & راهنمايى \\
\hline$F \mid / \Lambda$ & $11 / 4$ & IFA & دييلم ناقص \\
\hline $90 / 1$ & $r F / \cdot$ & rIr & ديّلم \\
\hline $\mathrm{V} / \mathrm{A}$ & $11 \%$ & Ifr & فوقدييلم \\
\hline $9 \Delta / 1$ & $1 / / r$ & rrv & 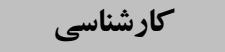 \\
\hline$৭ 9 / \mathrm{V}$ & $F / 9$ & 4. & كارشناسى ارشد ارشد \\
\hline १९/৭ & $\cdot / r$ & r & دكترى \\
\hline $1 \cdots /$ & $\cdot / 1$ & 1 & تحصيلات حوزوى \\
\hline
\end{tabular}


دييلم، Yq/Y درصد كاردانى و كارشناسى، Y/9 درصد كارشناسى ارشد و Y/• درصد نيز دكترى هستند.
بررسى ميزان تحصيلات وِاسخگويان نشان مىدهد تحصيلات كه 90/1 درصد از پِاسخگويان ديیلم و زير

جدول \& روابط مستقيم متغيرها

\begin{tabular}{|c|c|c|c|c|c|}
\hline معنى دارى & مقدار t & خطاندارد & استاندارد مقدار & بر آورد' & روابط مستقيم متغيرها در مدل \\
\hline $\mathrm{P}<\cdot / \cdot \Delta$ & $\cdot / A r r$ &.$/ 11 V$ &.$/ .94$ & $\cdot / \cdot 9 \mathrm{~V}$ & رابطه بين بعد قوميتى هويت با تمايزيافتكى \\
\hline $\mathrm{P}<\cdot / \cdot \Delta$ & $-\cdot / \Delta F F$ &.$/ .4 q$ & $-.1 .+49$ & $-\cdot / \cdot r \mid$ & رابطه بين سنت كرايى با تمايزيافتكى \\
\hline $\mathrm{P}<\cdot / \cdot \Delta$ & $r / T V F$ & 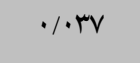 & $\cdot / r I I$ & ./Irr & رابطه بين بعد مذهبى هويت با تمايزيافتكى \\
\hline $\mathrm{P}<\cdot / \cdot 1$ & $r / V \cdot 9$ & $\cdot \cdots 1$ & $\cdot / \cdot M$ &.$/ r r$ & رابطه بين تحصيلات و تمايزيافتكى \\
\hline $\mathrm{P}<\cdot / \cdot 1$ & N/IFY & $\% \cdot .4$ &.$/ .94$ &.$/ \cdot 1 \mathrm{~V}$ & رابطه بين سن و تمايز يافتكى \\
\hline
\end{tabular}

آمده براى اين متغير برابر (TII خطاى استاندارد \&qه • •) نشان مىدهد كه فرضيه فوق در سطح 99 درصد اطمينان معنىدار است. نهايتاً اينكه نتايج، نشان مىدهد كه بين بعد قوميتى هويت و تمايز يافتكى رابطه مثبت و معنىدار وجود دارد؛ كه با افزايش هويت قومى، تمايز يافتكى افراد افزايش مى يابد ضريب به دست

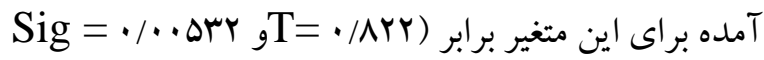
با خطاى استاندارد IIV / ) نشان مىدهد كه فرضيه فوق در سطح ه9 درصد اطمينان معنىدار است. دادههاى حاصل از بررسى عوامل مرتبط با متغير هويت فردى نشان مىدهد كه اين عامل از يككسو به طور مستقيم از عواملى جون هويت قومى با ضريب استاندارد (9194.) سنت گرايى بهصورت معكوس با ضريب استاندارد (4ץ./.) و متغير هويت مذهبى با ضريب استاندارد (III/ •) و متغير تحصيلات با ضريب استاندارد (MA)
نتايج مندرج در جدول شماره 9، نشان مىدهد كه بين بعد مذهبى هويت و تمايزيافتكى رابطه معنىدار و مثبتى وجود دارد؛ كه با افزايش بعد مذهبى هويت افراد، تمايزيافتگى افراد بالاتر مىرود. ضريب به دست آمده

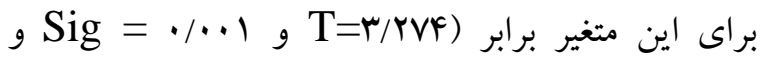
خطاى استاندارد ||//•) نشان مىدهد كه فرضيه فوق در سطح 99 درصد اطمينان معنىدار است. همجنين نشان مىدهد كه بين ميزان سنت گرايى و تمايزيافتكى رابطه معنىدار و منفى وجود دارد؛ كه با افزايش سنت گرايى افراد تمايزيافتكى افراد كمتر مىشود. ضريب به دست Tig = آمده براى اين متغير برابر ( با خطاى استاندارد وץ./•-) نشان مىدهد كه رابطه فوق در سطح هو درصد اطمينان معنىدار است. همجنين نشان مىدهد كه بين ميزان سن فرد و تمايز يافتكى رابطه معنىدار و مثبتى وجود دارد؛ كه با افزايش ميزان سن افراد، تمايز يافتخى افراد افزايش مىيابد. ضريب به دست 
مشترك را ناشى از شباهتهاى فيزيكى و شباهت در آداب و رسوم، حافظه و خاطرات مشتركى مىداند كه اين گرووها با يكديخر در كوج و سكونت داشتهاند

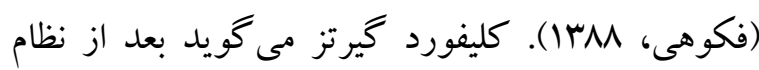
خويشاوندى، شايد قوميت مهمترين روش طبقهبندى و سازماندهى جمعى انسانها به شمار مى آيد (جنكينز،

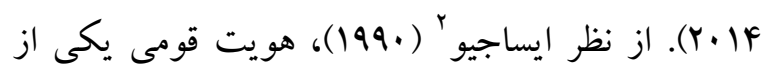
سطوح جامعهيذيرى تعريف مىشود كه فرد خود را با يك گروه بزرگك قومى متصل و مربوط مى كند و از آن طريق به صورت نمادين يا واقعى خود را عضو آن خروه مى يندارد. تاجفل هويت قومى را بخشى از مفهوم خود مىداند كه از آكاهى فرد نسبت به عضويتش در يكك كروه قومى با ارزشها و احساسات مربوط به آن ناشى مىشود. هلمز هويت قومى را احساس تعلق فرد به يكك كروه قومى مىداند كه اين كروه ميراث فرهنگ هودي،

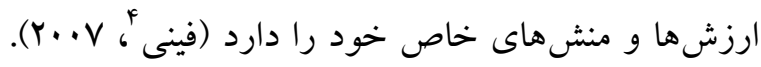
فينى (1999) با مطالعه تعداد بسيار زيادى از نوجوانان ( M M ( نفر )، تأثير هويت قومى را بر حرمت خود، اعتماد به خود در تحصيل و هدف زندگى در سه گروه آمريكايى سفيديوست، سياهيوستان و اسِانيايى زبانها و كروه سوم آسيايىهاى مقيم آمريكا مورد بررسى قرار داد. نتيجه اين بزوهش نشان داد كه آمريكايىهاى سفيد يوست، از بايين ترين، سياهيوستان و اسيانيايى زبانها از بالاترين ميزان هويت قومى و آسيايى ها در حد متوسط از هويت قومى برخوردار بودند. ديخر يافته جالب توجه در اين يزوهش اين است هر جه سطح هويت قومى افزايش داشته، به همان نسبت سطح حرمت خود، هدف زندكى و اعتماد به خود نيز افزايش نشان داده است. ارزشهاى
تأثير مىيذيرد. در اين بين كمترين اثر مستقيم بر هويت فردى را متغير سنت گرايى بهصورت معكوس با ضريب لين استاندارد (4 •/ •-.) داشته است.

هدف مطالعهى حاضر عبارت بود از بررسى ارتباط بين

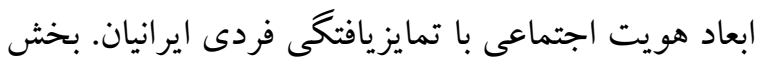
نتايج حاصل كندو كاو روابط بين متغيرهاست كه از طريق ضريب همبستخى به دست آمده است. همانطور كه در يافتهاى تحقيق مشاهده شد سنت گرايى رابطه معكوس با

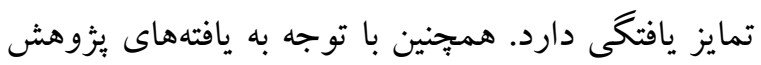
مىتوان كفت كه هرجه بعد قوميتى هويت فردى افراد بالاتر مىرود ميزان تمايز يافتكى فردى افراد نيز بالاتر مىرود. به اين صورت كه هرجقدر افراد با هويت قومى خود عجينتر بودند ميزان تمايز يافتخى فردى شخص هم بيشتر مىشود. اين يكك واقعيت است كه ساختار هويتى هر فرد از ارزشهاى مذهبى، ارزشهاى سنتى و بعد

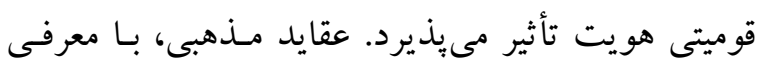
هدف نهايى آفرينش و پِاسخ به سؤالات وجودى فرد، نقش جشمخيرى در تشكيل هويت ايفا مى كند؛ و اين نشان مىدهد كه روابط متقابلى بين هويت مذهبى فرد با هويت فردى وجود دارد. شكل گيرى هويت فردى با تكيه بر مذهب و عوامل مذهبى و همجنين قدرت بخش هويت فردى بر تحكيم عوامل مذهبى فرد منجر مى شود. اولين تعريف مدرن از قوم و گُروههاى قومى را ماكس وبر

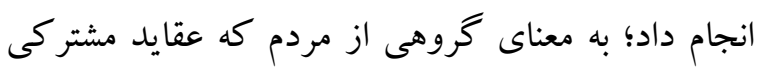
درباره ريشه هايشان دارند و بر اساس آن اجتماعى رابه

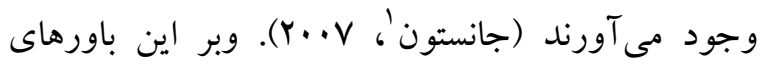

1. Janeston 
كه دين نوعى اعتقاد به وجودهاى معنوى يا مقدس است

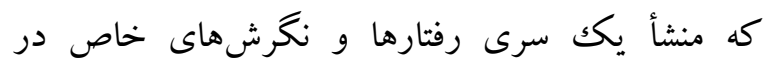
زندكى انسان مىشود. بـ انسان ديندار يا متدين نمىتواند با وجود يكى جنين اعتقادى عارى از هر گونه رفتار حاكى از باورهاى درونى خود باشد. بنابراين هر فرد با توجه به اينكه داراى اعتقادات و ارزشهاى مشتركى را با ساير افراد جامعه دارد؛ اما تمايزى در درونى كردن ارزشها و اعتقادات دينى در آنها ديده مىشود و در نهايت اين بعد مذهبى هويت بر تمايز يافتكى فردى منجر مى شود. اين يافته ها همسو با يافته هاى برجعلى و

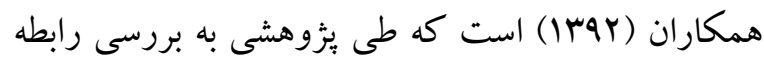
بين جهت گيرى مـذهبى و هويت فردى و وبرداختند. يافتهاى آنها نشان داد كه بين جهت گيرى مذهبى با هويت فردى، رابطه معنادار و مثبتى وجود دارد. بر طبق نتايج اين يزوهش M/M/9 درصد هويت فردى، بر اساس جهت گيرى مذهبى قابل تبيين است. با توجه به آنجه

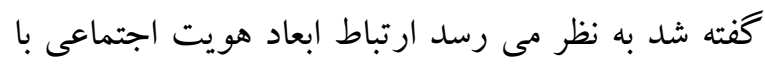
تمايز يافتكى فردى قابل تبيين است.

\section{نتيجه كيرى}

يافتهاى اين بزٔوهش حاكى از آن است كه از ميان ابعاد هويت اجتماعى هويت قومى و مذهبى به صورت مستقيم و سنت گرايى به صورت معكوس با ميزان تمايز يافتكى هو هو فردى در ارتباط است. همجنين بالا رفتن سن و و

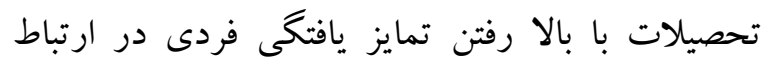
است. بر اين اساس مى توان نتيجه گرفت كه لايه هاى فردى و اجتماعى هويت با هم در ارتباط بوده و در جامعه ايرانى هويت اجتماعى و ابعاد متشكله آن نقش مهمى در تمايزيافتكى هويت فردى دارند و اين يلى است ميان

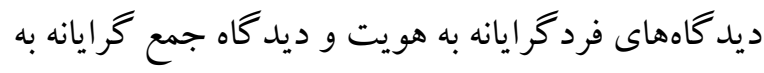

سنتى نيز در تشكيل و ساختار هويت افراد جامعه تأثيرات بسيار مهمى را ايفا مى كند. و باعث مىشود بهعنوان مؤلفهاى از هويت اجتماعى در ساختار تمايز يافتخىى

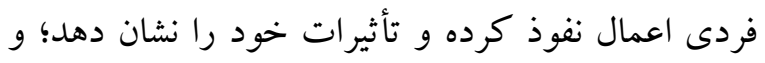
جرخه متغيرهاى ارزشهاى مذهبى، ارزشهاى سنتى و بعد قومى هويت بهعنوان هويت اجتماعى بر تمايز يافتخى فردى اثر دارند. در نهايت مى توان كفت بخش زئ زيادى از تمايز يافتكى فردى توسط ابعاد هويت اجتماعى تبيين مى تى ترى شود. همجينين يافته ها نشان داد كه كه با افزايش سنت

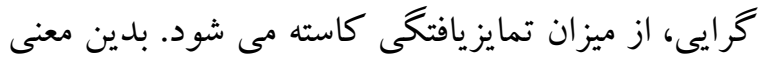
كه سنت ها باعث مى شوند افراد يكك شكل و همدست باشند و به تبعيت از سنت هاى جامعه هويت يكسانى را در خود يرورش دهند و هرجقدر از سنتها دور شوند بيشتر متمايز مىشوند و تفاوتهاى فردى خود را نشان مىدهند

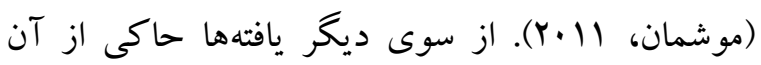

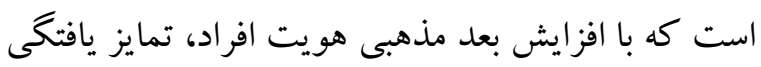
افراد بالاتر مىرود. به نظر مىرسد كه ساختار هويتى هر

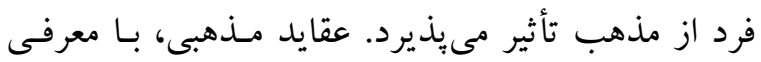
هدف نهايى آفرينش و پِاسخ به سؤالات وجودى فرد، نقش جشمخيرى در تشكيل هويت ايفا مى كند؛ و اين نشان مىدهد كه روابط متقابلى بين هويت مذهبى فرد با هويت فردى وجود دارد. شكل گيرى هويت فردى با تكيه بر مذهب و عوامل مذهبى و همجنين قدرت بخش هويت فردى بر تحكيم عوامل مذهبى فرد منجر مىشود (نونان،

دور كيم' (194F) در توصيف دين كفته است: دين نظام وحدت يافتهاى از باورها و اعمال در برابر اشياء مقدس است. (توسلى، ایم|) از تعاريف مزبور جنين برمى آيد

\footnotetext{
${ }^{1}$ - Durkheim
} 
developmental study. Journal of Family Research, 2(5), 35-46.

Phinney JS. (1990). Ethnic identity in adolescents and adults: Reviw of Research-Psychological Bulletin- Vol. 108, No.3.

Phinney JS. (2007). Ethnic identity exploration in emerging adulthood. American Psychological Association.

Sabatier Colelte. (2008). Ethnic and National Identity among second - generation immigrant adolescents in France. Journal of Adolescence31.

Shokra IZ. (2001). Examination and Comparison of Identity positions between Female and Male University Students. Women's Studies Sociological and Psychological, 2(5), 87-110. doi: 10.22051/jwsps.2004.1230.

Smaldino PE. (2019). Social identity and cooperation in cultural evolution. Behav Processes:;161:108116. doi:10.1016/j.beproc.2017.11.015.

Solgi M. (2011). Investigating the Dimensions and Components of Individual and Social Identity and those Influencing the National Identity among Tehran University Student with Structural Equation Modeling.

Yip T. (2006). African American Racial Identity across the Lifespan: Identity Status, Identity Content, and Depressive Symptoms. Chid Development. Vo.

$$
\begin{aligned}
& \text { آن تا به جاى بررسى اين بعد (فردى) يا آن بعد } \\
& \text { (اجتماعى) به بررسى نحوه ى ارتباط و يويايى ابعاد هويت } \\
& \text { بيردازيم. از جمله محدوديت هاى يُزوهش حاضر مى } \\
& \text { توان به عدم بررسى همزمان متغيرهاى تعديل گر و و } \\
& \text { واسطهاى و ساير ابعاد هويت برداخت كه ممكن است بر } \\
& \text { نحوهى ارتباط بين هويت اجتماعى و تمايزيافتكى فردى } \\
& \text { نقش داشته باشد. بر همين اساس به ساير يزوهشگران } \\
& \text { توصيه مىشود در تحقيقات آتى به اين مؤلفهها نيز }
\end{aligned}
$$

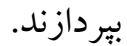

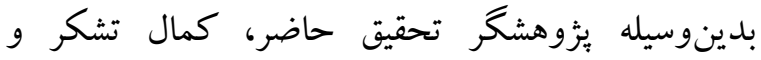

$$
\begin{aligned}
& \text { قدردانى خود را از تمام آزمودنىها در سراسر كشور كه } \\
& \text { با دقت تمام به برسشنامهها باسخ دادند، اعلام مىدارد. }
\end{aligned}
$$

\section{References}

Isajiw W. (1990). Ethnic identity retention in: R Berton, W. and Isajw. W kalbach and J. Reit, ethnic identity and equability, University of Toronto press.

Jenkins R. (2014). Social Identity, Routledge; 4 edition, 264 pages.

Montalbano Lori L. (2019). Gender, Race, and Social Identity in American Politics: The Past and Future of Political Access. Rowman \& Littlefield, - 308,PP.

Moshman D. (2011). Adolescent rationality and development: Cognition, morality, and identity(3rd ed.). New York: Psychology Press. ISBN: 9781848728615.

Noonan HW. (2019). Personal Identity. London: Routledge, https://doi.org/10.4324/9781315107240

Nosrati MS, Mazaheri MA, \& Heydari M. (2006). The Relationship Between Identity Status and Degree of Attachment in Male Adolescents (aged 14, 16\& 18) in Kamyaran: A 